\title{
UJI EFEKTIFITAS ANTIBAKTERI EKSTRAK KULIT BATANG JAMBU MONYET (Bellucia pentamera Naudin) TERHADAP PERTUMBUHAN BAKTERI Escherichia coli DAN Salmonella typhi
}

\author{
(Antibacterial Effectiveness Examination of Bellucia pentamera Naudin Bark Ekstracts Against \\ Escherichia coli and Salmonella typhi)
}

\author{
Farid Priandi, Fathul Yusro, Farah Diba, Yeni Mariani, Nurhaida
}

Fakultas Kehutanan Universitas Tanjungpura Jalan Imam Bonjol Pontianak 78124

Email: farid.priandi96@yahoo.co.id

\begin{abstract}
People still use plants as a medicine to overcome a disease, because it is easily to obtain and relatively does not provide significant negative effects. One of the plants utilized by the people is Bellucia pentamera Naudin (B. pentamera). Diarrhea and typhoid fever are diseases that often assault Indonesian people. The bacterias were used in this study were Escherichia coli (E. coli) and Salmonella typhi (S. typhi). This study aimed to analyze the antibacterial effectiveness of B. pentamera bark extracts against E. coli and S. typhi, by Kirby-Bauer diffusion method with PCA as the media. The highest extract concentration against $E$. coli is $400 \mathrm{mg} / \mathrm{ml}$ possess an inhibition of $20 \pm 1 \mathrm{~mm}$, and towards $S$. typhi is $80 \mathrm{mg} / \mathrm{ml}$ which possess an inhibition of $24.67 \pm 0,58 \mathrm{~mm}$.
\end{abstract}

Keywords: Bellucia pentamera, Disc Diffussion, Efectiveness, Escherichia coli, Salmonella typhi.

\section{PENDAHULUAN}

Manusia telah memanfaatkan beragam jenis tumbuhan yang tumbuh di dekat halaman rumah maupun hutan sebagai bahan obat-obatan untuk menyembuhkan beragam jenis penyakit. Pemanfaatan tumbuhan obat tersebut sudah dilakukan sejak zaman dahulu dan didokumentasikan dengan cara praktik turun-temurun yang terus berlangsung hingga sekarang. Indonesia sebagai bagian dari negara Asia memiliki sumberdaya tanaman obat yang berlimpah dan berpotensi dalam peningkatan ekonomi dan sosial masyarakat (Kumoro, 2015).

BPOM (Badan Pengawasan Obat dan Makanan) membagi 3 kategori obat dari sumber alam, yaitu: jamu, obat herbal terstandar (OHT), dan fitofarmaka (Hidayat, 2006). Obat-obatan kimia sintetis lebih praktis, karena berbentuk pil, tablet dan cair yang biasa digunakan untuk menyembuhkan berbagai penyakit, namun menurut Murdopo (2014) masyarakat memiliki kesadaran lebih untuk menggunakan obat dari bahan alam, dikarenakan harganya relatif murah, mudah didapat disekitar kita dan tidak memiliki efek samping yang berbahaya. Aljauziyyah (2011) mengatakan bahwa penggunaan obat modern (sintetis) secara berlebihan dapat menimbulkan efek samping yang berbahaya bagi kesehatan manusia.

Berdasarkan hasil penelitian tumbuhan obat dan jamu (RISTOJA), yang dilakukan oleh Balai Besar Penelitian dan Pengembangan Tanaman Obat dan Obat Tradisional (B2P2TOOT), Badan Litbang-Kementrian Kesehatan Republik Indonesia pada tahun 2012, menunjukkan bahwa terdapat 19.738 spesies tumbuhan yang berpotensi sebagai obat-obatan, 13.576 sudah teridentifikasi dan 1.740 
tergolong ke dalam 211 familia (Kumoro, 2015). Kalimantan Barat memiliki keanekaragaman tumbuhan obat yang beragam, seperti di Desa Kayu Tanam Kecamatan Mandor Kabupaten Landak terdapat 50 spesies dan yang dapat digunakan sebagai obat diare adalah Jambu Batu (Psidium guajava Linn.) dan yang digunakan untuk demam tifoid adalah Kunyit (Curcuma domestica Val.) dan Tikala Papuk (Erechtites hieracifolius (L) Raff.) (Efremila et al. 2015), di Desa Sungai Mawang Kecamatan Puring Kencana Kabupaten Kapuas Hulu terdapat 61 spesies, yang dapat digunakan sebagai obat diare adalah Engkuang (Dracontomelon dao (Blanco) Merr. \& Rolfe), Singkong (Manihot esculenta Crantz), Empapa (Macaranga sp.), dan Nami-nami (Cynometra cauliflora L.), dan yang digunakan sebagai obat demam tifoid adalah Sarang Bulu (Euphorbia hirta L.) (Pradityo et al. 2016).

Salah satu pemanfaatan tumbuhan obat di Indonesia adalah untuk mengatasi penyakit diare, karena penyakit ini masih merupakan masalah kesehatan masyarakat terutama di negara berkembang seperti Indonesia, dan juga menyebabkan kematian pada balita (Soepardi, 2011). Pada tahun 2013 penyakit diare ditetapkan sebagai Kejadian Luar Biasa (KLB) di Kecamatan Cermee Kabupaten Bondowoso, dan sampai pada bulan September 2015 jumlah penderita diare di Kabupaten Bondowoso sebanyak 22.791 orang (Rahman et al. 2016). Kasus diare pernah terjadi sebanyak 4.143 kasus di Kabupaten Kubu Raya pada tahun 2013, dan penyebab utama penyakit diare adalah bakteri Escherichia coli (E. coli) (Thresia et al. 2016; Vernanda et al. 2015).

Diare juga merupakan salah satu dari implikasi penyakit demam tifoid yang sangat endemik di Indonesia, dan sudah terinfeksi ke seluruh daerah semi perkotaan dengan angka morbitas 157/100.000 penduduk, disebabkan oleh bakteri Salmonella typhi (S. typhi) (Cita, 2011). Resistensi bakteri terhadap obatobatan antibakteri yang beredar saat ini cenderung meningkat, penemuan dan pengembangan obat-obatan baru yang lebih efektif dan aman diharapkan bisa mengatasi permasalahan ini (Katno et al. 2009).

Salah satu tumbuhan yang berpotensi sebagai obat adalah Bellucia pentamera (B. pentamera) atau di Pontianak disebut Jambu Monyet (Haryanti et al. 2015), di Entogong Kabupaten Sanggau disebut Jambu Lagan (Diba et al. 2013). Penggalian potensi $B$. pentamera sebagai antimikroba sudah dilakukan, dan terbukti mampu menghambat pertumbuhan bakteri (Marisa et al. 2017). Namun, sampai saat ini belum ada yang meneliti potensi dari kulit batangnya sebagai antibakteri, oleh karena itu perlu dilakukan penelitian pemanfaatan kulit batang $B$. pentamera sebagai bahan antibakteri.

\section{METODE PENELITIAN}

Penelitian ini dilakukan di Wood Workshop dan Laboratorium Teknologi Kayu Fakultas Kehutanan Universitas Tanjungpura, serta Laboratorium Kesehatan Daerah Pontianak. Alat-alat yang digunakan antara lain adalah meshscreen ukuran 40-60 mesh, water bath, inkubator, autoklaf, rotary evaporator, vortex, hammer mill, shaker, 
dan laminar airflow. Bahan-bahan yang digunakan antara lain kulit batang $B$. pentamera, bakteri E. coli dan S. typhi, metanol 96\%, antibiotik tetracycline, plate count agar (PCA), $\mathrm{BaCl}_{2} 1,175 \%$, asam sulfat $1 \%$, dan aquades.

\section{Prosedur Penelitian}

\section{Persiapan Sampel}

Kulit batang B. pentamera diambil dari pohon yang memiliki diameter 15 $20 \mathrm{~cm}$, di daerah Kecamatan Sungai Ambawang Kabupaten Kubu Raya. Kulit batang dibersihkan dari lumut dan kotoran lainnya dengan kain bersih, kemudian dipotong-potong menjadi ukuran yang lebih kecil menggunakan gunting, dan dikeringkan dengan cara dianginanginkan. Pembuatan serbuk dilakukan menggunakan hammer mill, selanjutnya serbuk yang diperoleh diayak hingga didapatkan ukuran lolos 40 mesh dan tertahan 60 mesh.

\section{Pengukuran Kadar Air}

Sebanyak 2 gram serbuk dimasukkan ke dalam wadah yang sudah diketahui beratnya, kemudian dimasukkan ke dalam oven dengan suhu $103 \pm 2^{\circ} \mathrm{C}$ selama 24 jam. Kemudian serbuk dimasukkan ke desikator untuk mengkondisikan suhu selama 15 menit dan ditimbang beratnya dengan timbangan analitik. Pengovenan dilakukan berulang sampai beratnya konstan. Kadar air serbuk diukur dengan rumus gravimetri berikut:

Keterangan:

$$
K A=\frac{\mathrm{W} 1-\mathrm{W} 2}{\mathrm{~W} 2} \times 100 \%
$$

$\mathrm{KA}=$ Kadar air $(\%)$

$\mathrm{W} 1=$ Berat serbuk awal $(\mathrm{g})$

$\mathrm{W} 2=$ Berat serbuk kering $(\mathrm{g})$

\section{Proses Ekstraksi}

Pengukuran Rendemen Ekstrak

Perhitungan rendemen ekstrak dengan cara serbuk diambil 1 gram kemudian direndam dengan metanol $96 \%$ dengan perbandingan 1:30, kemudian diaduk terus menerus dengan shaker selama 24 jam lalu disaring dan hasil saringan dimasukkan dalam wadah yang dikeringkan di atas waterbath. Perendaman dilakukan berulang sampai hasil saringan bening. Ekstrak kering yang diperoleh kemudian dilakukan penimbangan untuk mendapat berat ekstrak. Rendemen dihitung menggunakan rumus (Wijaya et al. 2018):

$$
\text { Rendemen }(\%)=\frac{\text { bobot ekstrak }(\mathrm{g})}{(1-\text { kadar air)bobot sampel (g) }} \times 100 \%
$$

Pembuatan Larutan Ekstrak Untuk Pengujian

Proses ekstraksi dilakukan dengan merendam serbuk kulit batang $B$. pentamera sebanyak $200 \mathrm{~g}$ dengan pelarut metanol $96 \%$ dengan perbandingan 1:7, campuran diaduk dengan shaker selama 24 jam. Larutan hasil ekstrak disaring dengan menggunakan kertas saring meteran, untuk memisahkan residu dengan larutan ekstrak, kemudian larutan ekstrak dievaporasi dengan mesin evaporator untuk memisahkan pelarut pada larutan ekstrak, sehingga yang dihasilkan berupa ekstrak kental, kemudian dikeringkan di atas waterbath untuk mendapatkan ekstrak padat.

\section{Pembuatan Konsentrasi Larutan Ekstrak}

Penelitian ini menggunakan 4 konsentrasi, yaitu $100 \mathrm{mg} / \mathrm{ml}, 200 \mathrm{mg} / \mathrm{ml}$, $300 \mathrm{mg} / \mathrm{ml}$, dan $400 \mathrm{mg} / \mathrm{ml}$ untuk pengujian pada bakteri $E$. coli, sedangkan untuk bakteri $S$. typhi menggunakan konsentrasi $20 \mathrm{mg} / \mathrm{ml}, 40 \mathrm{mg} / \mathrm{ml}, 60$ $\mathrm{mg} / \mathrm{ml}$, dan $80 \mathrm{mg} / \mathrm{ml}$. 
Pembuatan Media PCA (Plate Count Agar)

Ditimbang 17,5 gr PCA dan dimasukkan kedalam erlenmeyer kemudian ditambahkan $1000 \mathrm{ml}$ aquades. Selanjutnya dididihkan dengan hot plate sambil diaduk hingga larutan encer, kemudian ditutup dengan aluminium foil, dan disterilkan di dalam autoklaf dengan suhu $121^{\circ} \mathrm{C}$ dengan tekanan 2 atm selama 15 menit. Kemudian dimasukkan ke dalam cawan petri steril sebanyak 5-6 ml, didiamkan hingga media memadat. Komposisi PCA adalah tripton, ekstrak ragi, gukosa dan agar.

\section{Pembuatan Larutan Mc Farland 1}

Sebanyak 9,9 ml larutan asam sulfat $1 \%$ dimasukkan ke dalam erlenmeyer, kemudian ditambahkan sebanyak $0,1 \mathrm{ml}$ larutan $\mathrm{BaCl}_{2}$ 1,175\%, kemudian dikocok hingga terbentuk larutan keruh. Kekeruhan ini digunakan sebagai standar kekeruhan yang setara dengan standar Mc Farland 1 dengan konsentrasi bakteri 300x10 ${ }^{6} \mathrm{CFU} / \mathrm{ml}$ (Dasopang, 2017).

\section{Pembiakan Suspensi Bakteri}

Koloni bakteri diambil dengan menggunakan ose bulat steril, dimasukkan ke dalam tabung reaksi yang berisi larutan buffer phosphate kemudian dihomogenkan. Kekeruhan dibandingkan dengan standar kekeruhan Mc Farland 1, kemudian suspensi bakteri tersebut diambil menggunakan cotton bath steril dan digoreskan pada media PCA.

\section{Uji Daya Hambat Ekstrak terhadap Bakteri}

Metode pengujian ini menggunakan metode Kirby-Bauer, yaitu metode disc diffusion yang menggunakan kertas cakram berdiameter $5 \mathrm{~mm}$. Kertas cakram ditetesi ekstrak sebanyak 20 $\mu$, untuk $E$. coli konsentrasinya adalah $100 \mathrm{mg} / \mathrm{ml}, 200$ $\mathrm{mg} / \mathrm{ml}, 300 \mathrm{mg} / \mathrm{ml}$, dan $400 \mathrm{mg} / \mathrm{ml}$, dan untuk S. typhi konsentrasinya adalah 20 $\mathrm{mg} / \mathrm{ml}, \quad 40 \mathrm{mg} / \mathrm{ml}, \quad 60 \mathrm{mg} / \mathrm{ml}$, dan $80 \mathrm{mg} / \mathrm{ml}$, dan tetracycline $(30 \mu \mathrm{g})$ sebagai kontrol positif dan metanol $96 \%$ sebagai kontrol negatif, dengan tiga kali ulangan. Cakram yang sudah ditetesi tersebut diletakkan di atas permukaan media PCA yang telah diinokulasi bakteri $E$. coli dan $S$. typhi dengan pinset steril. Kemudian diinkubasi pada suhu $35-37^{\circ} \mathrm{C}$ selama 24 jam. Diameter hambatan diukur dengan penggaris oxoid.

Berdasarkan Mulyani et al. (2017), kategori zona hambat pertumbuhan bakteri ditunjukkan pada Tabel 1 berikut:

Tabel 1. Kategori Zona Hambat Pertumbuhan Bakteri

\begin{tabular}{cc}
\hline $\begin{array}{c}\text { Diameter Zona } \\
\text { Hambat }(\mathbf{m m})\end{array}$ & $\begin{array}{c}\text { Kategori } \\
\text { Hambatan }\end{array}$ \\
\hline$\geq 20$ & Kuat \\
$16-19$ & Sedang \\
$10-15$ & Lemah \\
$\leq 10$ & Sangat Lemah
\end{tabular}

Data yang diperoleh dianalisis dengan rancangan percobaan bentuk RAL (Rancangan Acak Lengkap), kemudian dilakukan uji lanjutan BNJ (Beda Nyata Jujur) menggunakan SPSS 2.1.

HASIL DAN PEMBAHASAN

\section{Rendemen Ekstrak Kulit Batang $B$. pentamera}

Rendemen merupakan suatu cara mengetahui mutu dari suatu ekstrak (Wijaya et al. 2018). Ekstrak kulit batang B. pentamera menghasilkan rendemen sebesar 23,51\% (dengan kadar air 12,66\%). Berdasarkan klasifikasi komponen kimia kayu Indonesia, 
rendemen ekstrak dari kulit batang $B$. pentamera tergolong tinggi karena memiliki kadar ekstrak $>4 \%$ (Departemen Pertanian, 1976). Selain itu, rendemen ekstrak dari kulit batang $B$. pentamera lebih besar dibandingkan beberapa ekstrak kulit batang tanaman lain seperti Lembawang (Mangifera sp.) dengan rendemen ekstrak 0,75\% (Adriyadi et al. 2016). Durio dulcis, Baccaurea angulata, Mangifera foetida, Mangifera pajang, Parkia timoriana, Dracontomelon dao, Pentasmadon motleyi, Durio kutejensis, Baccaurea costulata, Parkia speciosa, dan Parkia intermedia dengan rendemen sebesar 2,05-21,48\% (Yusro et al. 2016), Mangifera odorata sebesar 20,61\% (Prihatiningtyas et al. 2018) dan Eusideroxylon zwageri sebesar 21,63\% (Wila et al. 2018).

Besarnya rendemen ekstrak biasanya bervariasi tergantung pada spesies tumbuhan (Yusro et al. 2016). Pada jenis kayu tropis biasanya menghasilkan rendemen ekstrak sekitar 20\% (Tsoumis, 1991). Penggunaan metode ekstraksi dapat mempengaruhi jumlah ekstrak yang dihasilkan. Menurut Purwanto (2015), pada metode maserasi pelarut akan menembus dinding sel yang mengandung zat ekstraktif dan masuk ke dalam rongga sel sehingga zat aktif akan larut terbawa oleh pelarut, konsentrasi antara larutan zat aktif yang terikat di dalam sel memiliki perbedaan dengan konsentrasi pelarut, sehingga larutan yang terikat akan didesak keluar. Keuntungan penggunaan metode maserasi adalah pengerjaan dan peralatan yang digunakan sederhana serta dapat menghindari kerusakan komponen senyawa yang larut.

Besarnya rendemen juga dapat disebabkan oleh jenis pelarut yang digunakan. Metanol merupakan pelarut yang lebih baik dari pelarut lainnya, hal ini didukung oleh Adrianti et al. (2014), yang menyatakan bahwa penggunaan pelarut metanol lebih baik dibandingkan dengan penggunaan pelarut lainnya, karena metanol dapat menarik senyawa metabolit sekunder yang bersifat non-polar, semi polar dan polar. Diduga potensi senyawa yang terkandung di dalam $B$. pentamera adalah flavonoid, terpenoid dan tanin (Serna dan José, 2015).

\section{Uji Antibakteri}

Uji Aktivitas Antibakteri Pada Bakteri Uji E. coli

Hambatan pertumbuhan bakteri ditunjukkan pada zona bening di sekitar kertas cakram, diameter tertinggi zona hambat pada konsentrasi ekstrak 400 $\mathrm{mg} / \mathrm{ml}$ sebesar $19 \mathrm{~mm}$ dan yang terendah $100 \mathrm{mg} / \mathrm{ml}$ sebesar $5 \mathrm{~mm}$, sedangkan kontrol positif sebesar $26 \mathrm{~mm}$, dan kontrol negatif tidak menghambat sama sekali (Gambar 8).

Dari hasil uji BNJ diketahui bahwa ekstrak metanol kulit batang B. pentamera berpengaruh sangat nyata dalam menghambat pertumbuhan bakteri $E$. coli. Rerata diameter zona hambat esktrak metanol kulit batang $B$. pentamera terhadap pertumbuhan bakteri $E$. coli selengkapnya disajikan pada Gambar 1 berikut: 


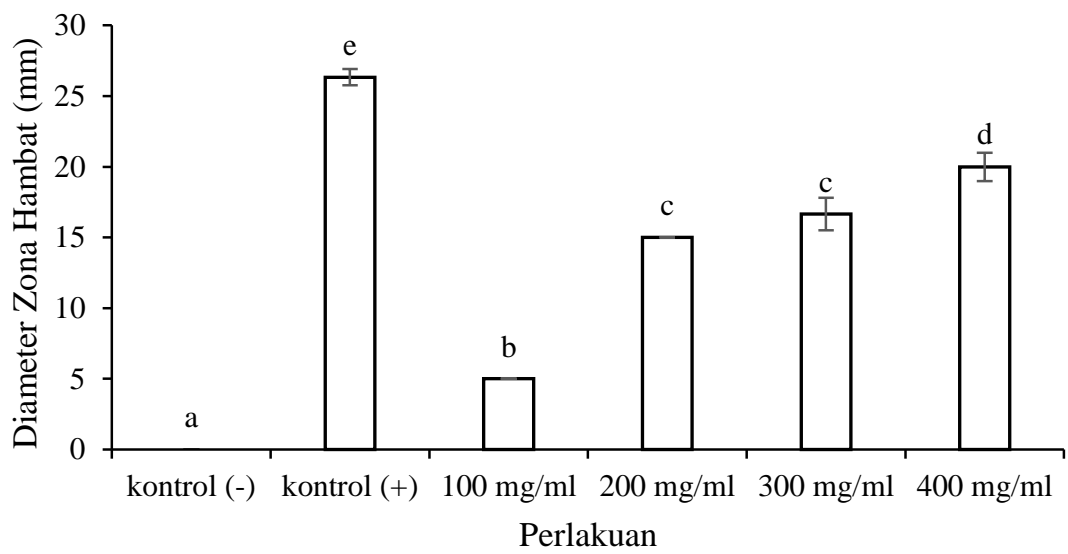

Gambar 1. Rerata \pm SD diameter zona hambat uji ekstrak kulit batang B. pentamera terhadap pertumbuhan bakteri E. Coli (Mean+Standard Deviation of inhibition zone diameter of Bellucia pentamera bark ekstract against Escherichia coli growth)

Keterangan: angka yang ditandai dengan huruf yang berbeda menunjukkan pengaruh berbeda nyata pada taraf kepercayaan 99\% (the mean are followed by the different letter are significantly different at the level of $99 \%$ )

Berdasarkan Gambar 1 di atas semua konsentrasi ekstrak kulit batang B. pentamera dapat menghambat pertumbuhan bakteri uji E. coli. Konsentrasi untuk menghambat pertumbuhan bakteri $E$. coli dengan diameter zona hambat $>15 \mathrm{~mm}$ tergolong tinggi yaitu $100 \mathrm{mg} / \mathrm{ml}$ keatas. Hasil ini lebih kecil jika dibandingkan dengan tanaman lain seperti ekstrak kulit batang Bridelia ferruginea dengan konsentrasi 25 dan $100 \mathrm{mg} / \mathrm{ml}$ mampu menghambat 15,3 dan 19,7 mm (Yunana et al. 2018), ekstrak kulit batang Eusideroxylon zwageri pada konsentrasi $200 \mathrm{mg} / \mathrm{ml}$ mampu menghambat pertumbuhan E. coli sebesar 24,33 mm (Wila et al. 2018), ekstrak kulit batang Mangifera odorata pada konsentrasi $200 \mathrm{mg} / \mathrm{ml}$ menghambat pertumbuhan E. coli $>20 \mathrm{~mm}$ (Prihatiningtyas et al. 2018). Namun, ekstrak kulit batang B. Pentamera lebih baik jika dibandingkan dengan beberapa tanaman lain seperti ekstrak kulit batang ceremai (Phyllanthus acidus L.) pada konsentrasi 100\% menghambat pertumbuhan E. coli sebesar 7,03 mm (Sernita et al. 2016), ekstrak metanol 1 kulit batang Phoenix dactylifera (Kurma) pada konsentrasi $100 \mathrm{mg} / \mathrm{m}$ menghambat pertumbuhan E. coli sebesar $11 \mathrm{~mm}$ (Al-daihan dan Bhat, 2012). Diduga kandungan senyawa aktif yang dihasilkan oleh ekstrak kulit batang B. pentamera tidak cukup banyak, sehingga berpengaruh terhadap efektifitasnya dalam menghambat pertumbuhan bakteri. 
JURNAL TENGKAWANG (2019)

Vol. 9 (1) : 27 - 37

Uji Aktivitas Antibakteri Pada Bakteri Uji S. typhi

Daya hambat kulit batang B. pentamera terhadap pertumbuhan bakteri S. typhi pada konsentrasi $80 \mathrm{mg} / \mathrm{ml}$ memiliki daya hambat paling besar dengan diameter zona hambat sebesar $25 \mathrm{~mm}$, dan yang terendah pada konsentrasi $20 \mathrm{mg} / \mathrm{ml}$ sebesar $10 \mathrm{~mm}$. Sedangkan kontrol positif sebesar $32 \mathrm{~mm}$, dan kontrol negatif tidak menghambat sama sekali.

Konsentrasi ekstrak 20, 40, 60, $80 \mathrm{mg} / \mathrm{ml}$ dan kontrol positif memberikan pengaruh yang sangat nyata dalam menghambat pertumbuhan bakteri S. typhi. Rerata diameter zona hambat esktrak metanol kulit batang $B$. pentamera terhadap pertumbuhan bakteri S. typhi selengkapnya disajikan pada Gambar 2 berikut:

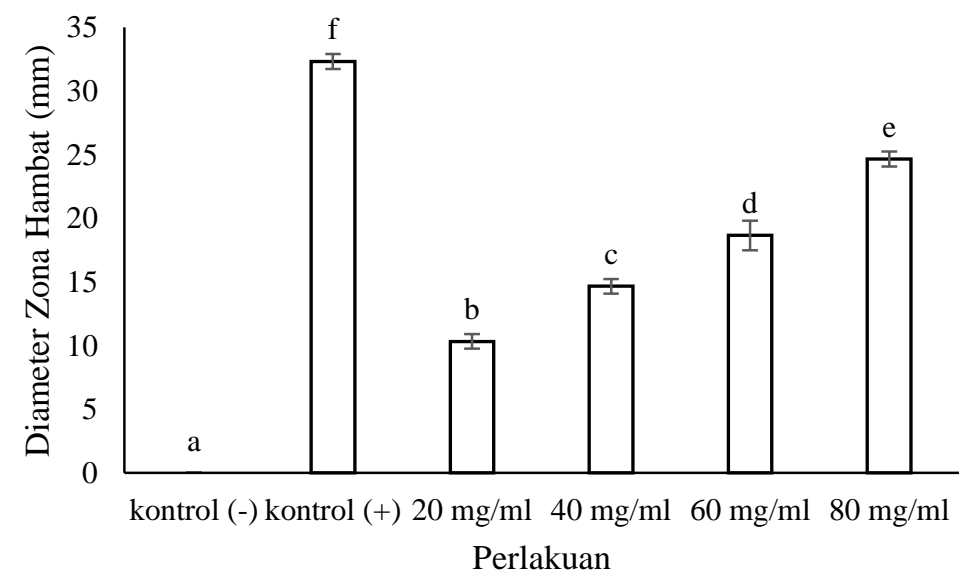

Gambar 2. Rerata \pm SD diameter zona hambat uji ekstrak kulit batang B. pentamera terhadap pertumbuhan bakteri $S$. typhi (Mean+Standard Deviation of inhibition zone diameter of Bellucia pentamera bark ekstract against Salmonella typhi growth)

Keterangan: angka yang ditandai dengan huruf yang berbeda menunjukkan pengaruh berbeda nyata pada taraf kepercayaan $99 \%$ (the mean are followed by the different letter are significantly different at the level of $99 \%$ )

Hambatan pertumbuhan bakteri $S$. typhi oleh ekstrak $B$. pentamera lebih besar dibandingkan ekstrak kulit batang tanaman lain seperti Avicennia marina yang hanya menghambat sebesar $7 \mathrm{~mm}$, Ceriops tagal sebesar $11 \mathrm{~mm}$, Rizhopora apiculata sebesar $12 \mathrm{~mm}$, Sonneratia alba sebesar $15 \mathrm{~mm}$, dan Sonneratia caseolaris tidak menghambat sama sekali (Mustopa et al. 2015), Angsana (Pterocarpus indicus Willd) dengan konsentrasi $75 \%$ hanya mampu menghambat pertumbuhan S. typhi sebesar 13,20 mm (Armedita et al. 2018) dan Sclerocarya birrea hanya mampu menghambat 20 mm (Manzo et al. 2017). Namun, ekstrak B. Pentamera pada konsentrasi 
$80 \mathrm{mg} / \mathrm{ml}$ memiliki daya hambat yang lebih kecil dibandingkan ekstrak kulit batang tanaman lain seperti Kemuning (Murraya paniculata (L) Jack) pada konsentrasi $75 \%$ sudah mampu menghambat pertumbuhan $S$. typhi sebesar $26 \mathrm{~mm}$ (Putra et al. 2018), dan Eusideroxylon zwageri pada konsentrasi $15 \mathrm{mg} / \mathrm{ml}$ sudah mampu menghambat pertumbuhan $S$. typhi sebesar $14,33 \mathrm{~mm}$ (Wila et al. 2018).

Senyawa aktif yang terkandung dalam $B$. pentamera belum ditemukan sumbernya, namum pada salah satu penelitian menyebutkan bahwa genus Bellucia mengandung senyawa aktif seperti flavonoid, terpenoid dan tanin (Serna dan José, 2015). Menurut Rijayanti et al. (2014), mekanisme kerja antibakteri tanin adalah dengan cara merusak protein. Tanin bereaksi dengan membran sel, kemudian menonaktifkan enzim dan menonaktifkan fungsi materi genetik (DNA) sehingga sel bakteri tidak dapat terbentuk, hal ini menyebabkan bakteri tidak dapat tumbuh dengan baik.

Mekanisme antibakteri flavonoid adalah dengan adanya reaksi antara gugus alkohol flavonoid dengan lipid dan asam amino pada dinding sel bakteri, sehingga dinding sel mengalami kerusakan. Senyawa flavonoid akan membentuk senyawa kompleks dengan protein, kemudian protein akan mengalami penggumpalan dan tidak dapat berfungsi, sehingga pertumbuhan bakteri terganggu (Heni et al. 2015).

Senyawa terpenoid adalah senyawa yang biasa ditemukan sebagai senyawa aromatik yang memiliki bau khas pada eucalyptus dan memberikan rasa tertentu pada kayu manis, cengkeh dan jahe, serta memberikan warna kuning pada beberapa jenis bunga. Mekanisme antibakteri terpenoid dapat menyebabkan terganggunya pembentukan membran dan dinding sel bakteri (Kurniawan dan Aryana, 2015).

Penelitian ini membuktikan bahwa ekstrak kulit batang $B$. pentamera mampu menghambat pertumbuhan $E$. coli dan $S$. typhi. Hal ini menunjukkan bahwa pemanfaatan $B$. pentamera oleh masyarakat sebagai tumbuhan obat terbukti secara ilmiah.

\section{Kesimpulan}

Berdasarkan hasil penelitian, maka dapat disimpulkan bahwa rendemen ekstrak kulit batang $B$. pentamera sebesar $23,51 \%$. Ekstrak metanol kulit batang $B$. pentamera dapat menghambat pertumbuhan bakteri E. coli dan S.typhi. Konsentrasi ekstrak $400 \quad \mathrm{mg} / \mathrm{ml}$ merupakan konsentrasi dengan daya hambat terbesar terhadap pertumbuhan bakteri uji E. coli yaitu sebesar $20 \mathrm{~mm}$. Konsentrasi ekstrak $80 \quad \mathrm{mg} / \mathrm{ml}$ merupakan konsentrasi dengan daya hambat terbesar terhadap pertumbuhan bakteri uji $S$. Typhi yaitu sebesar 24,67 mm.

\section{Saran}

Setelah dilakukan penelitian tentang pengaruh esktrak kulit batang $B$. pentamera dalam menghambat pertumbuhan bakteri E. coli dan S.typhi, maka disarankan perlu adanya penelitian lanjutan guna mengetahui kandungan fitokimia ekstrak kulit batang $B$. pentamera. Perlu adanya penelitian lanjutan guna mengetahui 
Kadar Hambat Minimum (KHM) ekstrak kulit batang B. pentamera. Perlu adanya penelitian lanjutan untuk mengetahui efektifitas ekstrak kulit batang B. Pentamera terhadap bakteri lain.

\section{DAFTAR PUSTAKA}

Adrianti H, Yotopranot S, dan Hamidah H. 2014. Efektivitas Ekstrak Daun Jeruk Purut (Citrus hystrix), Jeruk Limau (Citrus amblycarpa), Jeruk Bali (Citrus maxima) Terhadap Larva Aedes aegypti. Jurnal Aspirator 10 (6): 1-6.

Adriyadi D, Arreneuz S, Wibowo MA. 2016. Skrinning Fitokimia dan Uji Aktivitas Antioksiodan Ekstrak Metanol Kulit Batang Lembawang (Mangifera sp.). Jurnal Kimia Khatulistiwa 5(2): 1-5.

Albertus, Dewantara I, Herawatiningsih R. 2015. Jenis dan Potensi Tumbuhan Obat Pada Kawasan Hutan Adat Gunung Semarong Kecamatan Tayan Hulu Kabupaten Sanggau. Jurnal Hutan Lestari 3 (3): 446-455.

Aldaihan S Dan Bhat S. 2012. Antibacterial Activities of Extracts of Leaf, Fruit, Seed And Bark of Pheonix dactylifera. African Journal of Biotechology 11(42): 10021-10025.

Armedita D, Asfrizal V, Amir M. 2018. Aktivitas Antibakteri Ekstrak Etanol Daun, Kulit Batang, Dan Getah Angsana (Pterocarpus indicus Willd) Terhadap Pertumbuhan Streptococcus mutans. Dental Journal 5(1): 1-8.

Cita YP. 2011. Bakteri Salmonella typhi dan Deman Tifoid. Jurnal
Kesehatan Masyarakat 6 (1): 4246.

Dasopang ES. 2017. Skrining Fitokimia dan Uji Aktivitas Antibakteri Ekstrak Etanol Daun Sangitan (Sambucus javanica Reinw) Terhadap Pertumbuhan Bakteri Escherichia coli dan Salmonella typhi. BioLink. 4(1): 54-62.

Departemen Pertanian. 1976. Vademikum Kehutanan Indonesia. Direktorat Jendral Kehutanan, Jakarta.

Diba F, Yusro F, Mariani Y, Ohtani K. 2013. Inventory and Biodiversity of Medicinal Plants from Tropical Rain Forest Based on Tradisional Knowledge by Ethnic Dayaknese Communities in West Kalimantan Indonesia. Kuroshio Science 7(1): 75-80.

Haryanti ES, Diba F, Wahdina. 2015. Etnobotani Tumbuhan Berguna Oleh Masyarakat Sekitar Kawasan KPH Model Kapuas Hulu. Jurnal Hutan Lestari 3(3): 434-445.

Heni, Arreneuz S, Zaharah TA. 2015. Efektivitas Antibakteri Ekstrak Kulit Batang Belimbing Hutan (Baccaurea angulate Merr.) Terhadap Staphylococcus aureus Dan Escherichia coli. Jurnal Kimia Khatulistiwa 4(1): 84-90.

Kumoro AC. 2015. Teknologi Ekstraksi Senyawa Bahan Aktif dari Tanaman Obat. Yogyakarta: Plantaxia.

Kurniawan B dan Aryana WF. 2015. Binahong (Cassia alata L) As Inhibitor of Escherichia coli Growth. J Majority 4(4): 100-104.

Ledoh SMF, Lerrick RI, Ratu D. 2008. Aktivitas Antibakteri Escherichia 
coli pada Minyak Atsiri Batang Genoak (Acorus calamus) Asal Pulau Timor. Jurnal Ilmiah Kimia 8 (1): 1-8.

Manzo LM, Bako DH, Moussa I, Ikhiri K. 2017. Phytochemical Screening and Antibacterial Activity of Stem Bark, Leaf and Root Extract of Sclerocarya birrea (A. Rich.) Hochst. International Journal of Enteric Pathogens 5(4): 127-131.

Marisa H, Salni, Salfamas F, Oktariansyah Y. 2017. Studi Terhadap Bellucia pentamera Naudin Perubahan Status Invasif Menjadi Bermanfaat Larvasida. Prosiding Seminar Nasional 2017 Fakultas Pertanian UMJ, Sriwijaya, 8 November 2017. 4452.

Mulyani YWT, Hidayat D, Isbiyantoro, Fatimah Y. 2017. Ekstrak Daun Katuk (Sauropus androgynous (L) Merr) Sebagai Antibakteri Terhadap Propionibacterium acnes dan Stapylococcus epidermidis. Jurnal Farmasi Lampung 6(2): 46-54.

Mustopa AZ, Umami RN, Melki. 2015. Uji Aktivitas Antibakteri Ekstrak Mangrove Terhadap Salmonella typhi dan Listeria monocytogenes. Jurnal Ilmu dan Teknik Kelautan 7(2): 603-612.

Prihatiningtyas W, Mariani Y, Oramahi HA, Yusro F, Sisilia L. 2018. Uji Aktivitas Antibakteri Ekstrak Etanol Kulit Batang Mangga Kweni (Mangifera odorata Griff) terhadap Escherichia coli ATCC 25922 dan Salmonella typhi ATCC 25923. Jurnal Tengkawang 8(2): 59-74.
Purwanto S. 2015. Uji Aktivitas Antibakteri Fraksi Aktif Ekstrak Daun Senggani (Melastoma malabatricum L) Terhadap Escherichia coli. Jurnal Keperawatan Sriwijaya. 2 (2): 8492.

Putra IGPAFS, Juliantara IKP, Sukmayanti NLPA. 2018. Efektivitas Antibakteri Ekstrak Kulit Batang Kemuning (Murraya paniculata (L) Jack) Terhadap Pertumbuhan Salmonella typhi Secara Invitro. Jurnal Media Sains 2(1): 14-20.

Rijayanti RP, Luliana S, Trianto HF. 2014. Uji Aktivitas Antibakteri Ekstrak Etanol Daun Mangga Bacang (Mangifera foetida L.) Terhadap Staphylococcus aureus Secara In Vitro. Naskah Publikasi Program Studi Pendidikan Dokter Fakultas Kedokteran Universitas Tanjungpura.

Serna, DMO dan José HIM. 2015. Phenolics and Polyphenolics from Melastomataceae Species. Journal Molecules. 20 (10): 17818-17847.

Sernita, Fusvita A, Sumarni AL. 2016. Uji Kepekaan Kulit Batang Ceremai (Phyllanthus acidus L.) Terhadap Pertumbuhan Escherichia coli. Biowallacea 3(2): 455-466.

Wijaya H, Novitasari, Jubaidah S. 2018. Perbandingan Metode Ekstraksi Terhadap Rendemen Ekstrak Daun Rambai Laut (Sonneratia caseolaris L. Engl). Jurnal Ilmiah Manuntung 4(1): 79-83.

Wila H, Yusro F, Mariani Y. 2018. Skrinning Fitokimia dan Aktivitas Antibakteri Ekstrak Kulit Batang (Eusideroxylon zwageri) 
JURNAL TENGKAWANG (2019)

Vol. 9 (1) : 27 - 37

Terhadap Escherichia coli dan Salmonella typhi. Jurnal Tengkawang 8(1): 38-49.

Yunana BT, Bukar BB, Aguiyi JC. 2018. In Vitro and In Vivo Evaluation of Antibacterial Activity of Bridelia ferruginea Extracts On Some Clinical Isolates. The Journal of Phytopharmacology 7(4): 392398.

Yusro F, Ohtani K, Kubota S. 2016. Inhibition of $\alpha$-Glucosidase by Methanol Extracts from Wood Bark of Anacardiaceae, Fabaceae, Malvaceae and Phyllanthaceae Plants Family in West Kalimantan, Indonesia. Kuroshio science 9(2): 108-122. 